\title{
Nodular Fasciitis of the Face Diagnosed by US-Guided Core Needle Biopsy: A Case Report ${ }^{1}$
}

\author{
Sang Kwon Lee, M.D., Sun Young Kwon, M.D. ${ }^{2}$
}

\begin{abstract}
We report here on a case of nodular fasciitis (NF) that was diagnosed by ultrasonography (US)-guided core needle biopsy in a 31-year-old man, and we include the US and computed tomographic (CT) findings and the histopathologic findings at US-guided core needle biopsy (CNB). We suggest that high-resolution US is useful for the detailed evaluation of NF in the superficial regions, such as the face, and US-guided CNB is useful for the definitive histologic diagnosis of NF without causing scarring.
\end{abstract}

Index words : Soft tissues

Neoplasms

Ultrasound (US)

Fasciitis

Nodular fasciitis $(\mathrm{NF})$ is a benign, reactive, tumor-like proliferation of myofibroblasts that appears as a rapidly growing solitary mass. The most common locations are the extremities; this is followed by trunk, head and neck in decreasing order. A literature search yielded only a few reports concerning the imaging findings of NF (15). Most of those reports are focused on the computed tomographic $(\mathrm{CT})$ and magnetic resonance (MR) imaging findings of $\mathrm{NF}$ in the extremities and the neck. Ultrasonography (US) is the usual initial diagnostic modality for evaluating a palpable mass in the face. Thus, knowledge of the gray-scale and color Doppler US findings of $\mathrm{NF}$ is prerequisite for radiologists. A few reports (6- 8) have stressed the role of the fine needle aspiration cytology (FNAC) in the cytologic diagnosis of $\mathrm{NF}$ in the extremities, breast and face, but the role of USguided core needle biopsy (CNB) in the histologic diag-

${ }^{1}$ Departments of Diagnostic Radiology, Dongsan Medical Center, Keimyung University College of Medicine

${ }^{2}$ Departments of Pathology, Dongsan Medical Center, Keimyung University College of Medicine

Received May 13, 2006 ; Accepted June 13, 2006

Address reprint requests to : Sang Kwon Lee, M.D., Department of Diagnostic Radiology, Dongsan Medical Center, Keimyung University College of Medicine, 194 Dongsan-dong, Jung-gu, Daegu 700-712, Korea Tel. 82-53-250-7735 Fax. 82-53-250-7766 E-mail: sklee@dsmc.or.kr nosis of NF has not been discussed.

We report here on a case of NF of the face along with gray-scale and color Doppler US and CT findings, and we report on the role of US-guided CNB for the histologic diagnosis of NF of the face.

\section{Case Report}

A 31-year-old man presented with a palpable mass at the right cheek that was noticed 1 month earlier. There was no history of previous trauma. On physical examination, a firm, nontender, mobile mass about $3 \mathrm{~cm}$ in size was found at the right cheek. US demonstrated an approximately $2.5 \mathrm{~cm}$ sized lobular markedly hypoechoic solid mass in the right cheek that probably arose from the perioral muscle and it was protruding into the subcutaneous fat (Figs. 1A, B). Prominent vascularity was noted within the mass on the color Doppler images (Fig. 1C). Non-enhanced computed tomography (NECT) revealed a well circumscribed mass that was isoattenuated compared to the adjacent muscles, and it was mainly in the subcutaneous layer. The axial contrast-enhanced CT (CECT), and coronal and sagittal reformatted CECT images demonstrated a well-demarcated solid 
mass with slightly inhomogeneous, strong enhancement. The mass was inseparable from the perioral muscles (Fig. 2). The patients underwent US-guided CNB using an automated gun with an 18-gauge needle (Fig. 3A) without any skin incision. Histologically, the tissue cores consisted of short spindle cells and an intervening hyalinized matrix (Fig. 3B). The tumor cells were mostly fibroblasts arranged in short, irregular bundles and fascicles with intermixed lymphoid cells. We also noted mitotic figures and scattered foci of microhemorrhage between the bundles of fibroblasts (Fig. 3C). Immunohistochemically, the tumor cells showed strong positivity for vimentin (Fig. 4A) and orsmooth muscle actin (Fig. 4B). The patient underwent surgical excision of the mass through an intra-oral incision under general anesthesia. The gross specimen showed a well-demarcated, pale tan colored mass with rubbery consistency. The microscopic findings of the excisional biopsy were the same as those of US-guided CNB. The postoperative course was uneventful and there has been no evidence of neurologic deficits or recurrence for six months after the operation.

\section{Discussion}

In our hospital, US is the usual initial diagnostic modality for evaluating a palpable mass of the face. The recently available high-resolution scanner can well depict the relationship between the mass and the surrounding structures, and particularly in case of superficial lesions. There are no reports concerning the US findings of NF of the face in the English literature. However, there have been several reports concerning US findings of NF of the neck in the English literature $(3,5)$. According to them, the lesion was isoechoic in one patient, hypoechoic in one patient, and mixed iso- and hypoechoic in one patient. For one patient who underwent color Doppler US, low level vascularity was noted within a hypoechoic mass. The lesion in our case was markedly hypoechoic on the gray-scale images, and
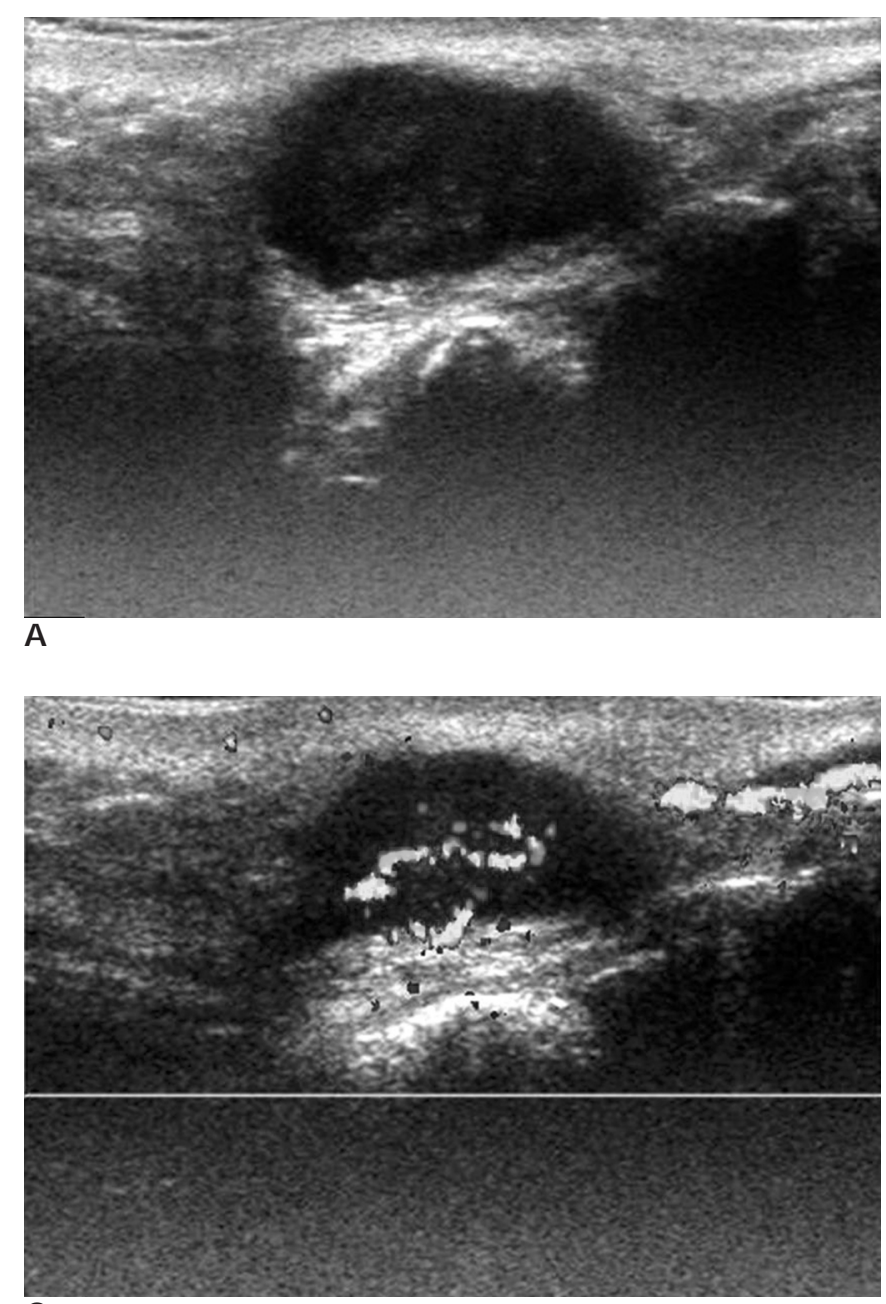

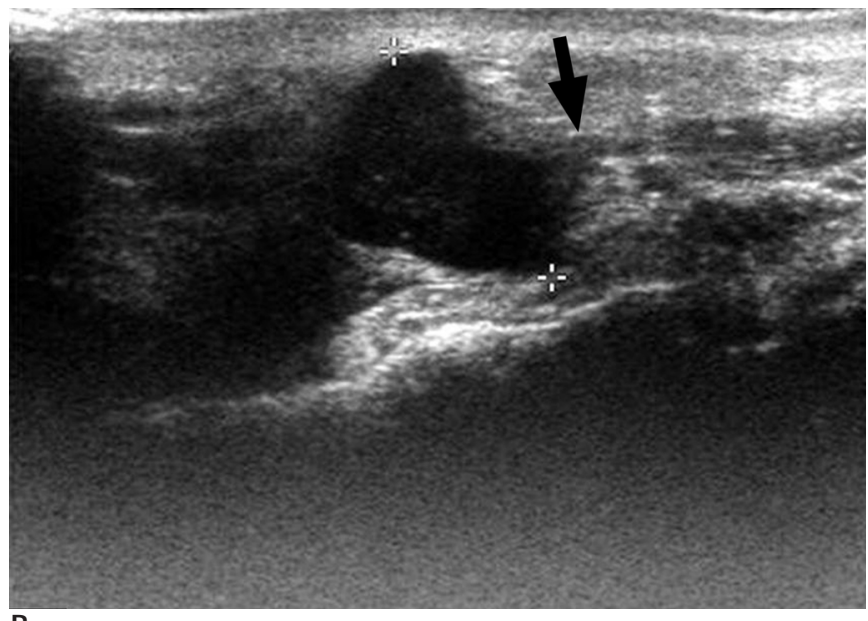

B

Fig. 1. Transverse (A) and longitudinal (B) ultrasonography (US) of the face demonstrate a markedly hypoechoic lobular solid mass arising from the perioral muscle (arrow) and protruding into the subcutaneous fat of the right cheek. Color Doppler US (C) reveals prominent vascularity within the mass. 

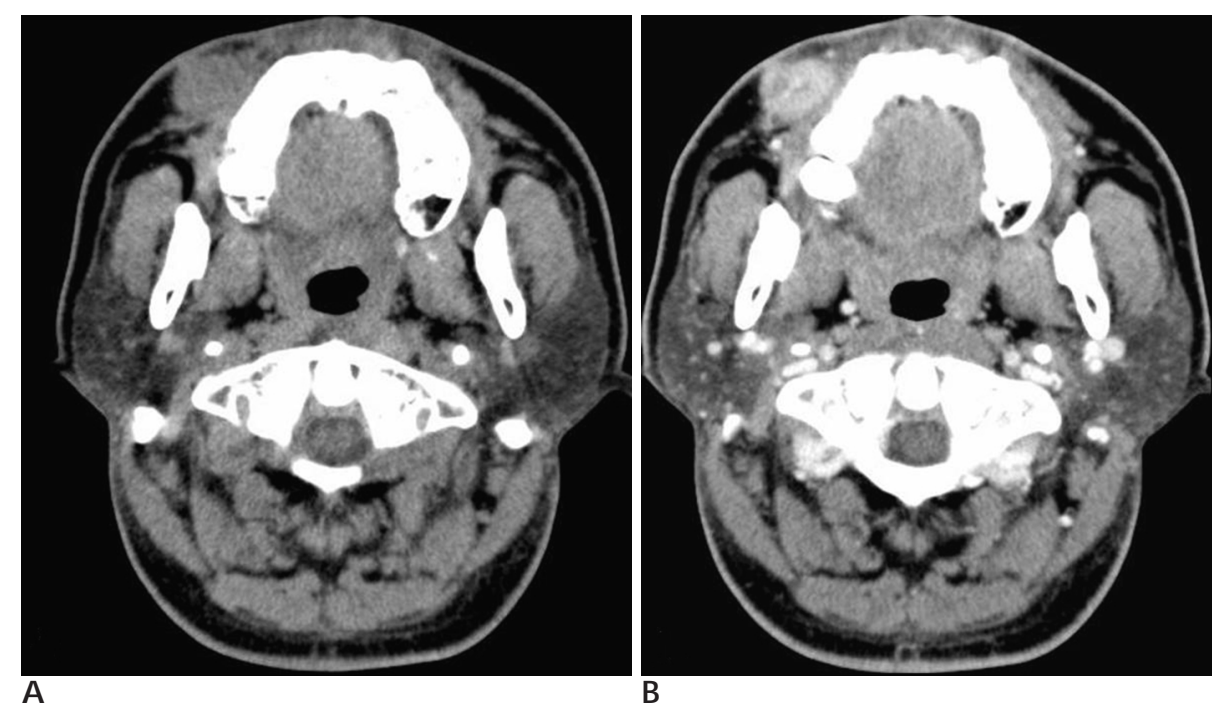

Fig. 2. Non-enhanced CT of the face (A) demonstrates a soft tissue mass that is isoattenuated to the adjacent muscles, and it is mainly in the subcutaneous layer of the right cheek. The axial contrast-enhanced CT $(\mathbf{B})$, coronal $(\mathbf{C})$ and sagittal (D) reformatted images reveal a lobular mass in the right cheek with slightly inhomogeneous, but strong enhancement.
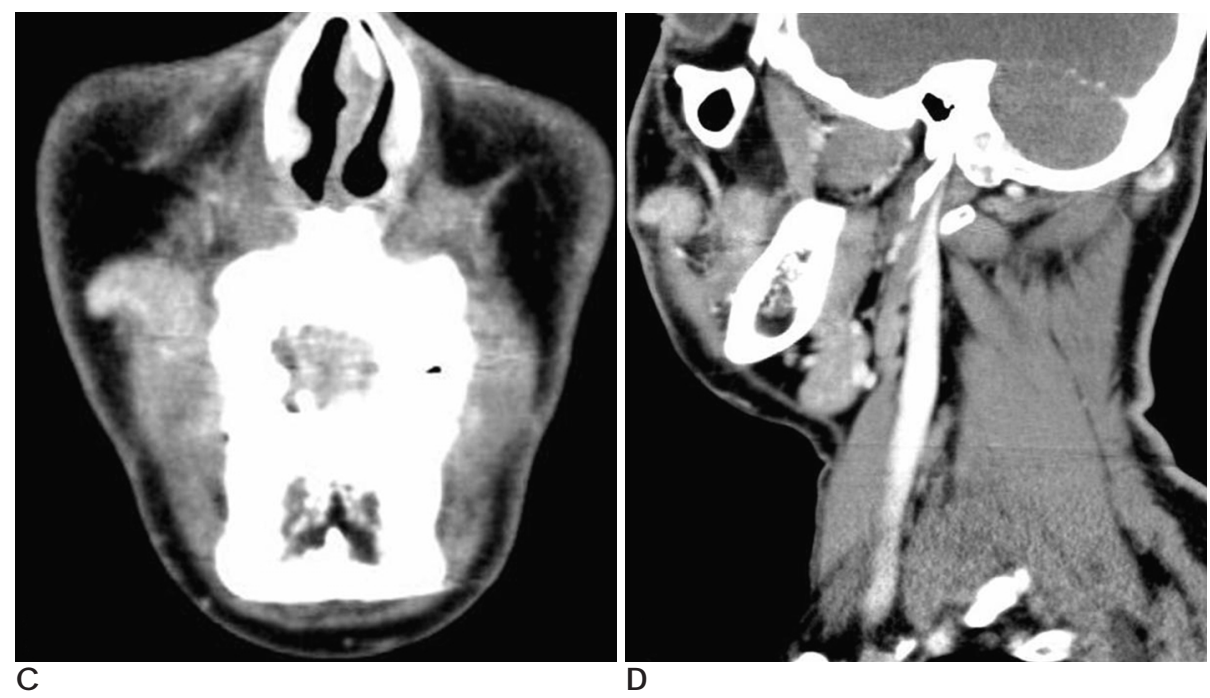

marked, prominent vascularity was noted within the mass on the color Doppler images. The differences in the echogenicity and color signals on US may reflect the subtypes of NF (i.e., the myxoid, cellular and fibrous types) and the variable vascularity contained in the individual lesions (9). The NECT and CECT findings of NF in our case were similar to those of previous reports in that there was a well demarcated lobular isoattenuating mass on NECT with strong, but slightly inhomogeneous enhancement on CECT.

The pathogenesis of NF remains unknown, but this is most probably a reactive condition that's triggered by local injury or infection rather than it being a true neoplasm. A history of previous trauma has been documented in only a small percentage of cases (4). The rapid growth and extension into surrounding tissues are similar to that is seen for malignant tumors. Thus, making the accurate preoperative diagnosis is important. NF is usually diagnosed by excisional biopsy (10); however, the problems encountered with surgical excision are anesthesia and scarring. Furthermore, NF may undergo spontaneous resolution $(6,10)$. Thus, performing a noninvasive diagnosis is mandatory. FNAC has been proved to be useful for making the cytologic diagnosis of $\mathrm{NF}$ (6- 8). The cytologic features of NF include a highly cellular smear that is predominantly composed of spindle cells that have a wide variety of sizes, and there is a background of myxoid substance (6). However, FNAC requires the skills of an experienced cytopathologist. We performed US-guided automated CNB with using an 18gauge needle without skin incision and we obtained a sufficient amount of the specimen for the histologic exam. Microscopically, the lesion was composed of spindle cells arranged in irregular bundles or fascicles, and this was usually accompanied by a small amount of collagen. We feel that US-guided core needle biopsy can re- 
place FNAC and excisional biopsy for making an accurate diagnosis and to avoid surgical scarring.

In conclusion, high-resolution US is useful for the detailed evaluation of the NF in the superficial regions, such as face, and US-guided CNB is useful for making the definitive histologic diagnosis of NF without causing scar.

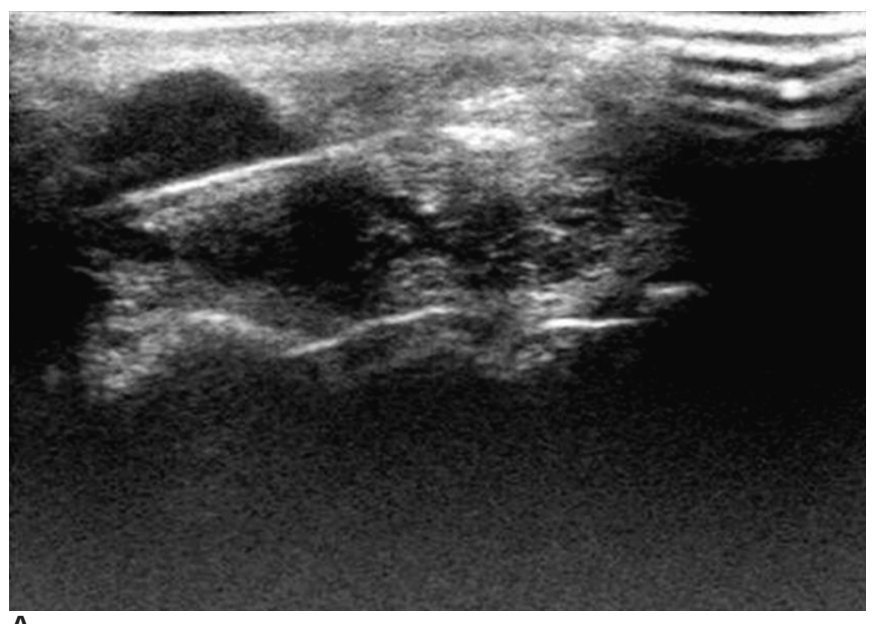

$\mathbf{A}$

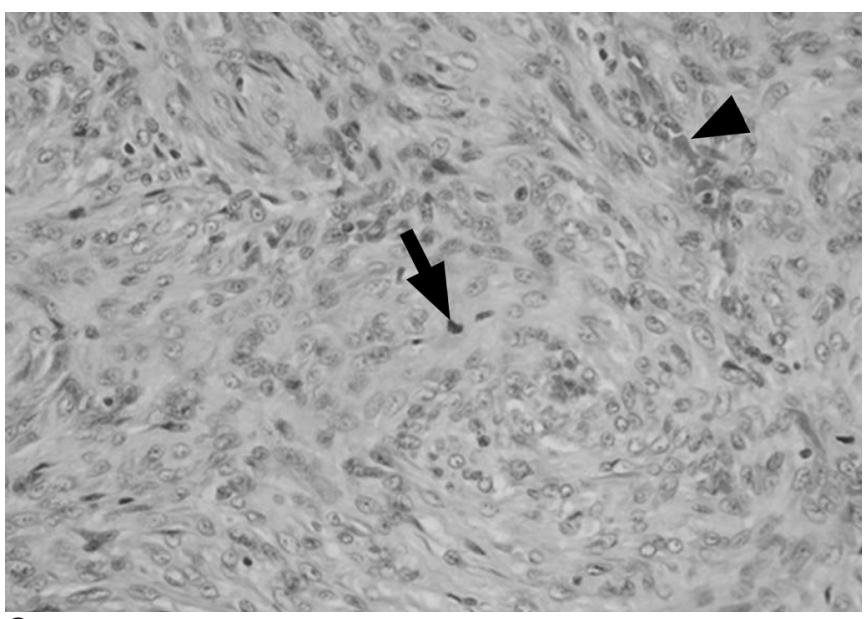

C

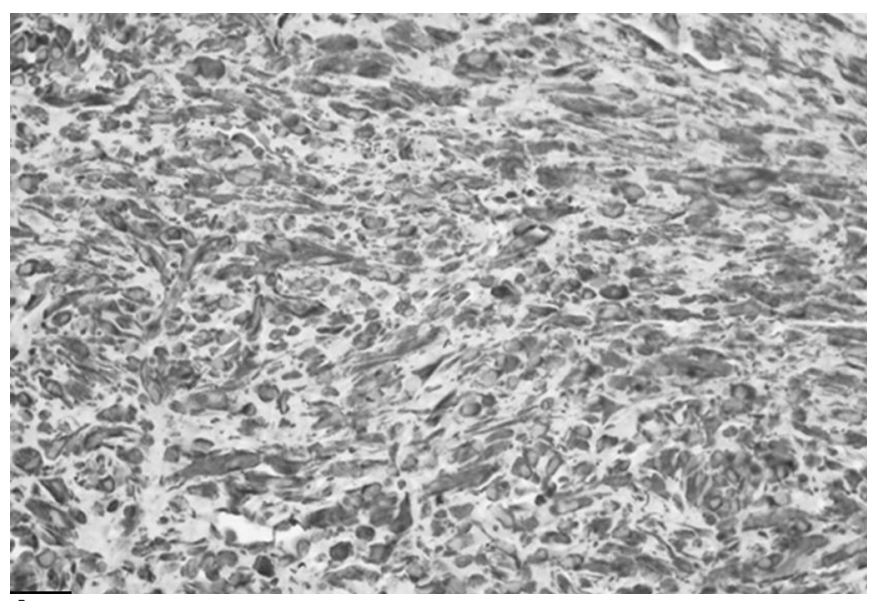

A

Fig. 4. Immunohistochemical staining show diffuse, strong positivity for vimentin $(\mathbf{A})(\times 400)$, and a-smooth muscle actin $(\mathbf{B})(\times$ 400).

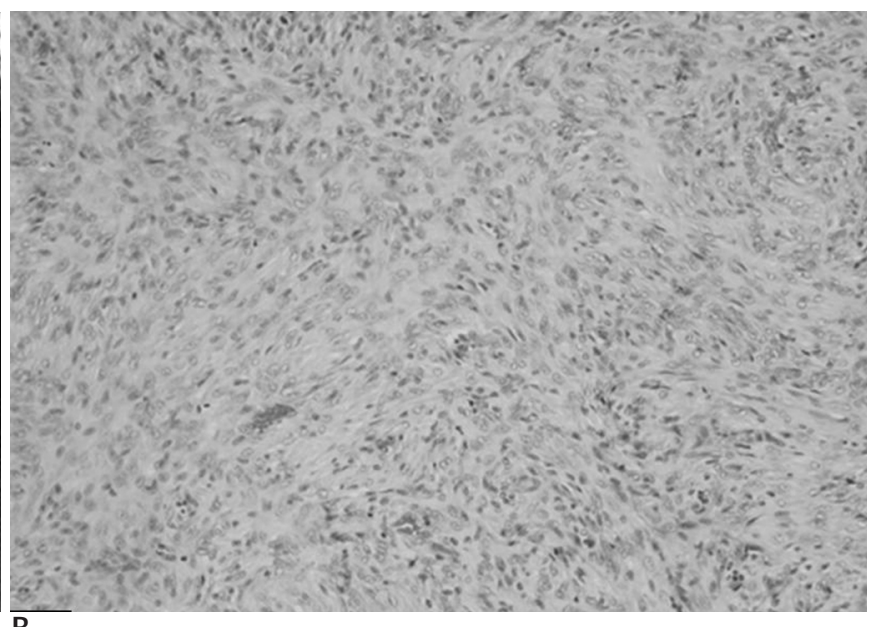

Fig. 3. A linear echogenic needle traversing the mass $(\mathbf{A})$ is noted during US-guided core needle biopsy. Microscopically, the tumor shows varying cellularity with areas of hypercellular spindle cell admixed with less cellular hyalinized areas $(\mathbf{B})(\mathrm{H} \& \mathrm{E}, \times$ 200). Mitotic figures (arrow) and foci of microhemorrhage (arrowhead) are noted between the bundles of fibroblasts $(\mathbf{C})(\mathrm{H}$ \& $\mathrm{E}, \times 400)$.

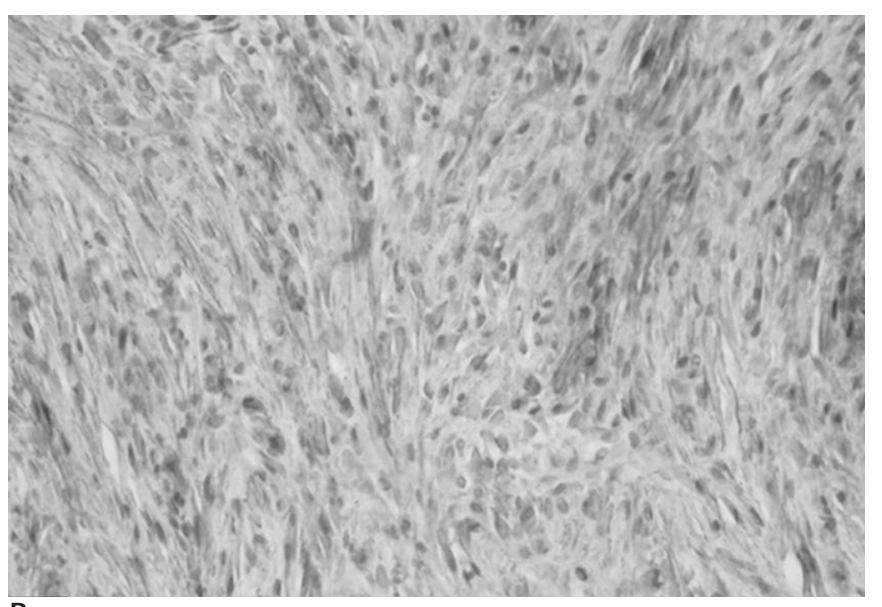

B 


\section{References}

1. Meyer CA, Kransdorf MJ, Jelinek JS, Moser RP. MR and CT appearance of nodular fasciitis. J Comput Assist Tomogr 1991;15:276279

2. Frei S, de Lange EE, Fechner RE. Case report 690: nodular fasciitis of the elbow. Skeletal Radiol 1991;20:468-471

3. Koenigsberg RA, Faro S, Chen X, Marlowe F. Nodular fasciitis as a vascular neck mass. AJNR Am J Neuroradiol 1996;17:567-569

4. Kim ST, Kim HJ, Park SW, Baek JH, Byun HS, Kim YM. Nodular fasciitis in the head and neck: CT and MR imaging findings. AJNR Am J Neuroradiol 2005;25:2617-2623

5. Shin JH, Lee HK, Cho KJ, Han MH, Na DG, Choi CG, et al.
Nodular fasciitis of the head and neck: radiographic findings. Clin Imaging 2003;27:31-37

6. Aydin O, Oztuna V, Polat A. Three cases of nodular fasciitis: primary diagnoses by fine needle aspiration cytology. Cytopathology 2001;12:346-347

7. Maly B, Maly A. Nodular fasciitis of the breast: report of a case initially diagnosed by fine needle aspiration cytology. Acta Cytol 2001;45:794-796

8. Matusik J, Wiberg A, Sloboda J, Andersson O. Fine needle aspiration in nodular fasciitis of the face. Cytopathology 2002;13:128-132

9. Price EB Jr, Silliphant WM, Shuman R. Nodular fasciitis: a clinicopathologic analysis of 65 cases. Am J Clin Pathol 1961;35:122-136

10. Stanley MW, Skoog L, Tani EM, Horwitz CA. Nodular fasciitis: spontaneous resolution following by fine-needle aspiration. Diagn Cytopathol 1993;9:322-324

대한영상의학회지 2006;55:551- 555

\title{
초음파유도하 핵 생검으로 진단된 안면부의 결절성 근막염: 1 예 보고 ${ }^{1}$
}

\author{
${ }^{1}$ 계명대학교 동산의료원 영상의학과 \\ ${ }^{2}$ 계명대학교 동산의료원 병리학과
}

이 상 권. 권 선 영

저자들은 핵 생검으로 진단된 31세 남자의 안면부에서 생긴 결절성 근막염을 초음파검사, 전산화단층촬영 및 초 음파유도하 핵 생검에 의한 병리 조직학적 소견과 함께 보고하고자 한다. 고해상능 초음파검사는 표재성의 결절성 근막염의 진단에 유용하며, 초음파유도하 핵 생검은 피부의 반흔을 남기지 않는 조직학적 확진을 위한 유용한 검사 방법으로 생각된다. 